\title{
Neuropeptide Y Gene Promoter -399T/C Polymorphism Increases Risk of Ischemic Stroke
}

\author{
Xue-Feng Fu, Xin Zhang, Dong-Jun Wang, Bo Zhao, Yu-Rong Li \\ $3^{\text {rd }}$ Department of Cadres, Lanzhou General Hospital of Lanzhou Military Area Command of Chinese PLA, Lanzhou, China
}

\begin{abstract}
Background: Several genetic factors underlying ischemic stroke have been identified. Variants of Neuropeptide Y (NPY), whose product plays diverse roles in modulating physiological functions, have been associated with an increased risk of ischemic stroke in South Korean individuals.

Aims: We explored the association between a polymorphism in the NPY gene promoter at position -399 and the risk of ischemic stroke in Han Chinese. Study Design: Case-control study.

Methods: The polymorphism -399T/C in the promoter of NPY was analysed in 500 patients with ischemic stroke and 500 healthy individuals by amplification and sequencing of this region. Non-conditional logistic regression was used to analyse association between genotypes and the risk of ischemic stroke.

Results: Genotype and allele frequencies differed significantly between the ischemic stroke and control groups $(\mathrm{P}<0.05)$. Additionally, compared to stroke patients with the TT genotype, those with the CC genotype had a 1.7-times higher risk of ischemic stroke $(\mathrm{OR}=1.739,95 \% \mathrm{Cl}=1.201-2.520, \mathrm{P}=0.003)$, especially for those who were over 60 years old or male. Individuals with the TC genotype did not have an increased risk of ischemic stroke (P>0.05).

Conclusion: The -399T/C polymorphism of the NPY gene is associated with ischemic stroke in Han Chinese individuals, and the CC genotype may be a risk factor for ischemic stroke.
\end{abstract}

Key Words: Ischemic stroke, Neuropeptide Y, Gene polymorphisms

Received: 21.10.2012 Accepted: 11.01.2013

\section{Introduction}

Stroke is a major cause of death and disability (1). Most commonly, strokes result from ischemia, which is caused by multiple risk factors and manifests as a variety of complex diseases with heterogeneous function disorders (2-3). Of the many risk factors, genetic factors play significant roles in the aetiology and incidence of stroke in both animal models and humans (4-5). Indeed, some single-gene disorders can cause ischemic stroke (6), and current research using candidate gene studies and genome-wide association studies seeks to identify additional genes that contribute to stroke.

One gene with the potential to contribute to stroke aetiology is Neuropeptide Y (NPY). NPY is a neuroactive peptide that is widely distributed in the central and peripheral nervous systems. It acts as an important neuroendocrine modulator (7) and is involved in regulating a variety of physiological functions such as inhibiting norepinephrine and epinephrine responses (8), stimulating the proliferation of vascular smooth muscle cells (9), and capillary development (10). Some studies have shown that genetic variants of NPY are associated with an increased risk of hypertension (11), atherosclerosis (12), and coronary artery disease (13). Because these diseases underlie the pathological changes leading to ischemic stroke, NPY itself may act as a risk fac- tor for ischemic stroke. In fact, in animal models of cerebral infarction, NPY expression levels are increased in cortical and subcortical tissues around the lesions (14). Furthermore, Lee et al. (15) reported that two polymorphisms in NPY, $4112 \mathrm{C} / \mathrm{T}$ and $6411 \mathrm{~A} / \mathrm{C}$, significantly increase the risk of ischemic stroke. However, the NPY promoter region -399T/C polymorphism is associated with the initiation of transcription and can change NPY transcription activity (16); when the -399 locus contains the $C$ nucleotide, plasma NPY levels are higher (12). This polymorphism is also correlated with risk of ischemic stroke in Korean populations (17).

One study identified the presence of variants in NPY that increase the risk of ischemic stroke in Han Chinese populations (18). Here, polymerase chain reaction (PCR) and gene sequencing were used to detect the genotype and allele frequencies of the NPY gene promoter -399T/C alleles in 500 patients with ischemic stroke and 500 healthy control subjects. The relationship of this polymorphism with the incidence of ischemic stroke was assessed.

\section{Material and Methods}

\section{Study subjects}

We recruited 500 ischemic stroke patients who were hospitalised in Lanzhou General Hospital of Lanzhou Military Area

Address for Correspondence: Xue-Feng Fu, Third Department of Cadres, Lanzhou General Hospital of Lanzhou Military Area Command of Chinese PLA, Rd. 98 of Xiaoxihuxijie, Qilihe District, Lanzhou City 730050, Gansu Province, P. R. China Phone: +86 9318994501 e-mail: fuxflanzhou@126.com 
Command of Chinese PLA between January 2010 and December 2011. This group ("ischemic stroke") included 345 males and 155 females, with a mean age of $62.9 \pm 9.6$ years. All patients were diagnosed with ischemic stroke by neurological evaluation and head CT or MRI. Patients were excluded if diagnosed with cerebral embolisms caused by atrial fibrillation, tumour, and emboli sources, as well as renal insufficiency and hepatic insufficiency. Clinical symptoms and past medical history were provided by the patients themselves or their families. The control group included 500 healthy individuals selected from those who received physical examination in our hospital during the same time period. This group included 317 males and 183 females, with a mean age of $62.0 \pm 9.4$ years. No statistically significant difference was observed in age or gender distribution between the two groups. All participants provided informed consent, and the study was approved by the institutional review board.

\section{Specimen collection and DNA preparation}

Samples of peripheral venous blood were taken from all participants in a fasting state and preserved in a refrigerator at $-20^{\circ} \mathrm{C}$. Wizard genomic DNA extraction kits (Promega, USA) were used to extract genomic DNA from blood samples according to the manufacturer's protocol. DNA concentration and purity were then determined using the ND-1000 UV/VIS spectrophotometer (Nanodrop Corporation, USA), and template DNA concentration was adjusted to 25 to $50 \mathrm{ng} / \mu \mathrm{L}$.

\section{Polymerase chain reaction}

Primers to amplify the NPY promoter region were synthesised by the Sangon Biological Engineering Technology Co. (Shanghai, China). Sequences were as follows: upstream, 5'-CAACAGGTTTAACGCGATGAGCA-3'; downstream, 5'-AGAGATAGGAGCA GCCCAGACGAT-3'. DNA was amplified using the following reaction mix $(25 \mu \mathrm{L}$ total volume): $2 \mu \mathrm{L}$ DNA template, $2.5 \mu \mathrm{L} 10 \times$ buffer, $2 \mu \mathrm{L}$ dNTPs, 1 $\mu \mathrm{L}$ each primer, $2 \mathrm{U}$ Taq DNA polymerase, and $16.5 \mu \mathrm{L} \mathrm{ddH_{2 }} \mathrm{O}$. Samples were amplified under the following conditions: $94^{\circ} \mathrm{C}$ for $5 \mathrm{~min} ; 30$ cycles of $94^{\circ} \mathrm{C}$ for $1 \mathrm{~min}, 57^{\circ} \mathrm{C}$ for $1 \mathrm{~min}$, and $72^{\circ} \mathrm{C}$ for $1 \mathrm{~min}$; and $72^{\circ} \mathrm{C}$ for $10 \mathrm{~min}$. PCR products were visualised on a $2 \%$ agarose gel. Successfully amplified PCR products were then sequenced ( $A B I$, USA).

\section{Statistical analysis}

SPSS17.0 statistical software was used for statistical analysis. Two-sample $t$-test was used to compare ages and the $\chi^{2}$ test was used to compare gender and genotype and allele frequencies between the two groups. The relationship between gene polymorphisms and ischemic stroke was analysed with odds ratio (OR) by non-conditional logistic regression analysis and its $95 \%$ confidence interval $(\mathrm{Cl}) . \mathrm{p}<0.05$ was considered statistically significant.

\section{Results}

NPY promoter -399T/C genotype and allele frequencies

The amplified DNA fragment containing the NPY promoter $-399 \mathrm{~T} / \mathrm{C}$ polymorphic locus was $668 \mathrm{bp}$ in size (Figure 1).
When amplified DNA was sequenced, the nucleotide sequence of the amplification product was consistent with the expected sequence (Figure 2). Sequencing of amplification products allowed the determination of the presence of the $\mathrm{T}$ or $\mathrm{C}$ allele at position -399. The genotype distribution of NPY promoter -399T/C was consistent with Hardy-Weinberg equilibrium in both patients with ischemic stroke and control individuals ( $p>0.05)$. However, statistically significant differences between the two groups were observed for both genotype and allele frequencies (Table 1; $\mathrm{p}<0.05$ ).

Relationship between genotype frequency and ischemic stroke

Non-conditional logistic regression analysis indicated that the risk of ischemic stroke increased by 1.7 times ( $O R=1.739$, 95\% $C l=1.201-2.520, p=0.003$ ) in stroke patients with the CC genotype compared to those with the TT genotype (Table 2). Furthermore, risk of ischemic stroke was significantly higher in patients with CC genotype who were male or over 60 years old $(p<0.05)$; in contrast, the risk was not higher in females patients or those under 60 years old $(p>0.05)$. The risk of ischemic stroke was not increased in patients with the TC genotype.

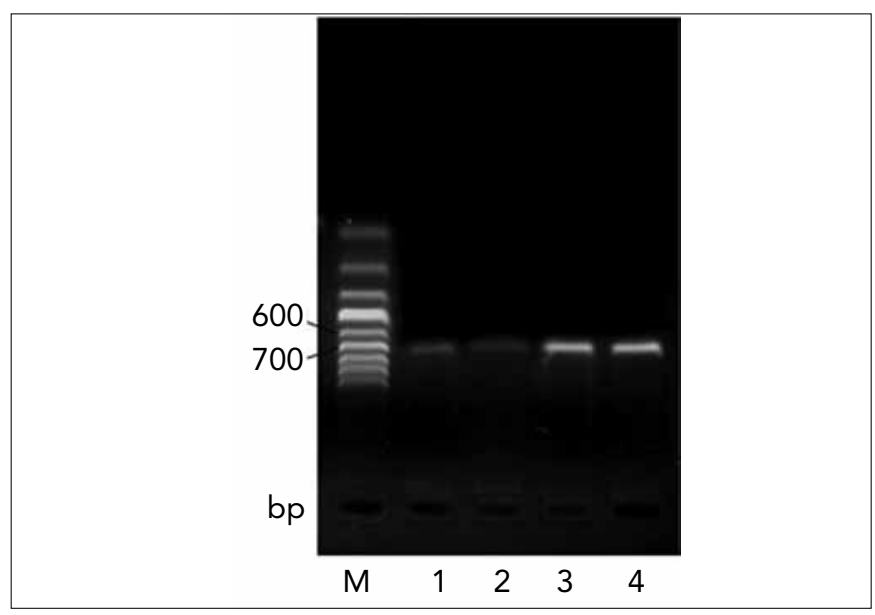

Figure 1. Electrophoresis results of PCR of the region surrounding the NPY gene promoter -399T/C polymorphism Lane M: DNA standard molecular weight; Lane 1-2: Poor PCR product; Lane 3-4: Good PCR product

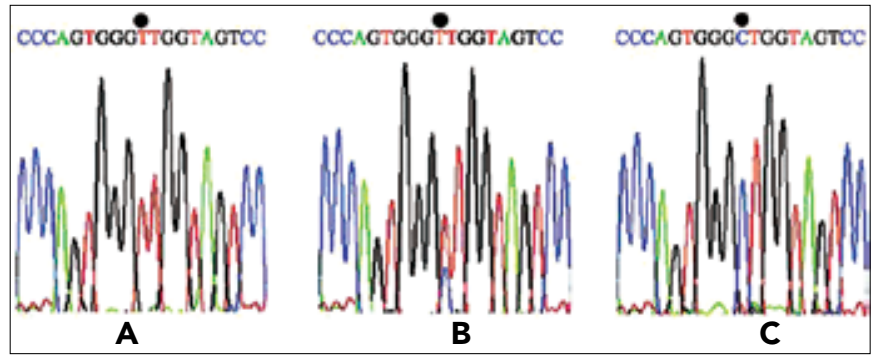

Figure 2. Sequenced PCR products for determination of NPY gene promoter -399T/C polymorphism status

A: TT genotype; B: TC genotype; C: CC genotype. 
Table 1. Comparison of genotype and allele frequencies between groups [n (\%)]

\begin{tabular}{|c|c|c|c|c|c|c|}
\hline \multirow[t]{2}{*}{ Group } & \multirow[t]{2}{*}{$\mathbf{n}$} & \multicolumn{2}{|c|}{ Genotype } & \multicolumn{2}{|c|}{ Allele } & \multirow[b]{2}{*}{ C } \\
\hline & & TT & TC & CC & $\mathrm{T}$ & \\
\hline Ischemic Stroke & 500 & $64(12.8)$ & $231(46.2)$ & $205(41.0)$ & 359 (35.9) & $641(64.1)$ \\
\hline Control & 500 & $101(20.2)$ & $213(42.6)$ & $186(37.2)$ & $415(41.5)$ & 585 (58.5) \\
\hline$\chi^{2}$ & & & 9.950 & & 6.610 & \\
\hline$P$ & & & 0.007 & & 0.010 & \\
\hline \multicolumn{7}{|c|}{$\begin{array}{l}\text { CV-P: cardiovascular disorder-positive; CV-N: cardiovascular disorder-negative; M/F: Male/Female; ODI: oxyhemoglobin desaturati- } \\
\text { on index; Al: apnea index; HI: hypopnea index. } \\
\text { All comparisons showed that these groups were similar in terms of T-allele distribution. } \\
{ }^{*} p<0.01 \text { with respect to CV-P CC genotype, }{ }^{+} p<0.01 \text { with respect to CV-P CT genotype }\end{array}$} \\
\hline
\end{tabular}

Table 2. Association between genotype frequency and ischemic stroke

\begin{tabular}{|c|c|c|c|c|c|}
\hline Variable & Genotype & $\begin{array}{c}\text { Ischemic Stroke } \\
\text { [n (\%)] }\end{array}$ & $\begin{array}{l}\text { Control } \\
\text { [n (\%)] }\end{array}$ & OR $(95 \% \mathrm{Cl})$ & $p$ \\
\hline \multirow[t]{3}{*}{ Total } & TT & $64(12.8)$ & $101(20.2)$ & Reference & \\
\hline & $\mathrm{TC}$ & $231(46.2)$ & $213(42.6)$ & $1.016(0.774-1.334)$ & 0.907 \\
\hline & $\mathrm{CC}$ & $205(41.0)$ & $186(37.2)$ & $1.739(1.201-2.520)$ & 0.003 \\
\hline \multirow[t]{3}{*}{$<60$ years old } & TT & $27(14.1)$ & $44(21.9)$ & Reference & \\
\hline & $\mathrm{TC}$ & $85(44.5)$ & $76(37.8)$ & $0.872(0.563-1.351)$ & 0.540 \\
\hline & $\mathrm{CC}$ & $79(41.4)$ & $81(40.3)$ & $1.589(0.898-2.812)$ & 0.112 \\
\hline \multirow[t]{3}{*}{$\geq 60$ years old } & $\mathrm{TT}$ & $37(12.0)$ & $57(19.1)$ & Reference & \\
\hline & $\mathrm{TC}$ & $146(47.2)$ & $137(45.8)$ & $1.126(0.795-1.595)$ & 0.504 \\
\hline & $\mathrm{CC}$ & $126(40.8)$ & $105(35.1)$ & $0.964(1.135-3.012)$ & 0.014 \\
\hline \multirow[t]{3}{*}{ Male } & TT & $43(12.5)$ & $88(27.8)$ & Reference & \\
\hline & $\mathrm{TC}$ & $159(46.1)$ & $104(32.8)$ & $0.748(0.530-1.056)$ & 0.099 \\
\hline & $\mathrm{CC}$ & $143(41.4)$ & $125(39.4)$ & $2.341(1.513-3.623)$ & 0.001 \\
\hline \multirow[t]{3}{*}{ Female } & TT & $21(13.5)$ & $13(7.1)$ & Reference & \\
\hline & $\mathrm{TC}$ & $72(46.5)$ & $109(59.6)$ & $0.629(0.236-1.368)$ & 0.242 \\
\hline & $\mathrm{CC}$ & $62(40.0)$ & $61(33.3)$ & $0.969(0.969-2.443)$ & 0.068 \\
\hline
\end{tabular}

\section{Discussion}

NPY is well known for its roles in modulating hormone secretion, body temperature regulation, biological rhythms, and other physiological functions. It also plays an important role in the regulation of central and peripheral nervous systems, the cardiovascular system, and blood pressure self-stabilisation (15). Additionally, NPY is a plasma biomarker that can indicate stroke, although its expression does not differ based on the type (ischemic vs. hemorrhagic) of stroke (19). Studies in animal models have demonstrated that NPY increases around brain lesions, and that administration of NPY following stroke increases infarct volume and decreases reperfusion $(14,20)$. Therefore, NPY is an important contributor in stroke biology.

Here, we demonstrate that polymorphism in the NPY promoter at position -399 influences the risk of ischemic stroke in Han Chinese individuals, consistent with previous findings in South Korean and Chinese populations $(17,18)$. Both previous studies found that the $C$ allele confers a higher risk of stroke. Indeed, we found that, compared to the TT genotype, the risk of stroke significantly increased in those with the CC genotype. Furthermore, we extended the previous studies by stratifying for age and sex: the CC genotype was significantly associated with stroke in those aged $\geq 60$ years and in males. Therefore, the $C$ allele may confer an increased susceptibility to ischemic stroke.

It is well known that, due to declined physiological function, those aged $\geq 60$ years are more likely to develop ischemic stroke; males are also more vulnerable because of alcohol and tobacco use and other environmental factors (21). Despite these trends, it is interesting to note that the $-399 \mathrm{C}$ allele associates with stroke in males and individuals $\geq 60$ years. It is possible that the $C$ allele interacts with other genetic and environmental factors to increase stroke risk in certain populations. However, genetic polymorphism and allele frequencies have racial differences, and research in other ethnic groups is required to extend these findings.

In summary, the NPY gene promoter -399T/C polymorphism is associated with ischemic stroke, with the CC genotype conferring an increased risk for these events. Because ischemic stroke is the result of multiple genes and environ- 
mental factors, single-gene studies cannot fully clarify interactions between genes and the combined effects of multiple genes on the phenotype. Therefore, additional analyses on multiple genetic loci are required to identify other genes influencing the risk of these events.

Ethics Committee Approval: Ethics committee approval was received for this study from the Ethics Committee of Lanzhou General Hospital of Lanzhou Military Area Command of Chinese PLA.

Informed Consent: Written informed consent was obtained from patients who participated in this study.

Peer-review: Externally peer-reviewed.

Author contributions: Concept - X.F., X.Z., D.W., B.Z., Y.L.; Design - X.F., X.Z., D.W., B.Z., Y.L.; Supervision - X.F.; Resource - X.Z., D.W., B.Z., Y.L.; Materials - X.Z., D.W., B.Z., Y.L.; Data Collection\&/or Processing - D.W., B.Z., Y.L.; Analysis\&/or Interpretation - D.W., B.Z., Y.L.; Literature Search - X.F., Y.L.; Writing - X.F.; Critical Reviews - X.Z., D.W., B.Z., Y.L.

Conflict of Interest: No conflict of interest was declared by the authors.

Financial Disclosure: No financial disclosure was declared by the authors.

\section{References}

1. Feigin VL. Stroke epidemiology in the developing world. Lancet 2001;365:2160-1. [CrossRef]

2. Eltzschig HK, Eckle T. Ischemia and reperfusion--from mechanism to translation. Nat Med 2011;17:1391-401. [CrossRef]

3. Rodriguez-Hernández A, Josephson AS, Langer D, Lawton MT. Bypass for the prevention of ischemic stroke. World Neurosurg 2011;76:S72-9. [CrossRef]

4. Flossmann E, Sehulz UG, Rothwell PM. Systematic review of methods and results of studies of the genetic epidemiology of ischemic stroke. Stroke 2004;35:212-27. [CrossRef]

5. Jerrard-Dunne P, Cloud G, Hassan A, Markus HS. Evaluating the genetic component of ischemic stroke subtypes: a family history study. Stroke 2003;34:1364-9. [CrossRef]

6. Meschia JF, Worrall BB, Rich SS. Genetic susceptibility to ischemic stroke. Nat Rev Neurol 2011;7:369-78. [CrossRef]

7. Lundberg JM, Terenius L, Hökfelt T, Martling CR, Tatemoto K, Mutt $V$, et al. Neuropeptide $Y$ (NPY) like immunoreactivity in peripheral noradrenergic neurons and effects of NPY on sympathetic function. Acta Physiol Scand 1982;116:477-80. [CrossRef]
8. Walker P, Grouzmann E, Burnier M, Waeber B. The role of neuropeptide $\mathrm{Y}$ in cardiovaseular regulation. Trends Pharmacol Sci 1991;12:111-5. [CrossRef]

9. Erlinge D, Brunkwall J, Edvinsson L. Neuropeptide $Y$ stimulates proliferation of human vascular smooth muscle cells: cooperation with noradrenaline and ATP. Regul Pept 1994;50:259-65. [CrossRef]

10. Zukowska-Grojec Z, Karwatowska-Prokopczuk E, Rose W, Rone $\mathrm{J}$, Movafagh S, Ji H, et al. Neuropeptide Y: a novel angiogenic factor from the sympathetic nerves and endothelium. Circ Res 1998;83:187-95. [CrossRef]

11. Renner W, Grammer T, Hoffmann MM, Nauck MS, Winkelmann $\mathrm{BR}$, Boehm BO, et al. Association analysis of the polymorphism T1128C in the signal peptide of neuropeptide $Y$ in a Swedish hypertensive population. J Hypertens 2004;22:2398-9. [CrossRef]

12. Itokawa $M$, Arai $M$, Kato $S$, Ogata $Y$, Furukawa A, Haga S, et al. Association between a novel polymorphism in the promoter region of the neuropeptide $\mathrm{Y}$ gene and schizophrenia in humans. Neurosei Lett 2003;347:202-4. [CrossRef]

13. Shah SH, Freedman NJ, Zhang L, Crosslin DR, Stone DH, Haynes $C$, et al. Neuropeptide Y Gene polymorphisms Confer Risk of Early-Onset Atherosclerosis. PLoS Genet 2009;5:e1000318. [CrossRef]

14. Kharlamov EA, Kharlamov A, Kelly KM. Changes in neuropeptide $Y$ protein expression following photothrombotic brain infarction and epileptogenesis. Brain Res 2007;1127:151-62. [CrossRef]

15. Lee $C$, Kong $M$. An interactive association of common sequence variants in the neuropeptide $\mathrm{Y}$ gene with susceptibility to ischemic stroke. Stroke 2007;38:2663-9. [CrossRef]

16. Buckland PR, Hoogendoorn B, Guy CA, Coleman SL, Smith SK, Buxbaum JD, et al. A high proportion of polymorphisms in the promoters of brain expressed genes influences transcriptional activity. Biochim Biophys Acta 2004;1690:238-49.

17. Kim NS, Oh SM, Ko MM, Cha MH, Kang BR, Bang OS. Association of the C-399T promoter polymorphism of neuropeptide $\mathrm{Y}$ with susceptibility to ischemic stroke. Clin Biochem 2009;42:1699704. [CrossRef]

18. Yu JT, Yu NN, Gao SS, Song JH, Ma T, Wang ND, et al. Neuropeptide $Y$ polymorphisms and ischemic stroke in Chinese population. Clin Chim Acta 2010;411:242-5. [CrossRef]

19. Montaner J, Mendioroz M, Delgado P, García-Berrocoso T, Giralt $D$, Merino $C$, et al. Differentiating ischemic from hemorrhagic stroke using plasma biomarkers: the S100B/RAGE pathway. J Proteomics 2012;75:4758-65. [CrossRef]

20. Chen SH, Cheung RT. Peripheral and central administration of neuropeptide $\mathrm{Y}$ in a rat middle cerebral artery occlusion stroke model reduces cerebral blood flow and increases infarct volume. Brain Res 2002;927:138-43. [CrossRef]

21. Mustacchi P. Risk factors in stroke. West J Med 1985;143:186-92. 